\title{
INFLUENCE OF THE MEDICAL RAW MATERIAL PROCESSING WITH HIGH PRESSURE ON THE ANTIOXIDANTS EXHAUSTION WHILE WATER EXTRACTION
}

\author{
Влияние обработки лекарственно-технического сырья \\ высоким давлением на извлечение антиоксидантов \\ при водной экстракции
}

Pastushkova E.V., Khabarov S.N. Пастушкова Е.В., Хабаров С.Н.

\section{Abstract}

The article concerns the influence of the medical raw materials (MRM) processing with the high pressure on the antioxidants exhaustion while water extraction. The MRM use in the food industry is a promising area of food fortifying with bioactive substances including antioxidants that are to increase respiratory disease resistance of the human body. This problem is mostly actual for the population living in areas with unfavorable environmental conditions. The main aim of the research is to scrutinize the MRM high-pressure processing (HPP) influence on the biologically active substances (BAS) output. The research objects are the medical raw materials, i.e. stinning nettle, peppermint, wild majoram, garden sage, sanguinary, amber, thymus, whortleberry leave, black currant leave and cherry leave gathered in the 2015-2016 in ecologically favorable Nizhneserginskiy and Shalinskiy areas of the Sverdlovsk region. Researchers treated the dried medical raw material with high pressure at a temperature of $200^{\circ} \mathrm{C}$ in the Multivac system as following: they packed the MRM sample weighing $50 \mathrm{~g}$ in a vacuum transparent package at the preparatory stage, placed in a loading container, brought them to the high-pressure room. Researchers generated the pressure of 100, 150 and 200 MPa by the room pump during 60 and 90 seconds. While the high-pressure processing there was an increase in the ascorbic acid amount in the whortleberry leaf essence by $63 \%$, and in the stinging nettle by $72 \%$; the total flavonoids content in the dried cherry leaf raised by $37 \%$, and in the wild majoram - by $3 \%$, respectively, compared to the control samples. The optimal processing parameters of the medical raw materials are to be the pressure treatment of $150 \mathrm{MPa}$ during 90 seconds and of $200 \mathrm{mPa}$ during 60 seconds. These high-pressure processing parameters contribute to the molecules and cell junctions that influence positively the BAS extraction in the medical raw materials essence. The scientists concluded that while the pressure and time rising the antioxidative activity (AOA) and the biologically active substances of the analyzed medical raw materials boost after processing.

\section{Реферат}

В статье рассмотрено влияние метода обработки лекарственно-технического сырья (ЛтС) высоким давлением на извлечение антиоксидантов при его водной экстракции. Использование лТС в пищевой промышленности - перспективное направление обогащения пищевых продуктов биологически активными веществами, в том числе антиоксидантами, основной задачей которых является повышение резистентности организма человека к респираторным заболеваниям. Наиболее акту-

Keywords:

medical raw materials;

antioxidants;

bioactive substances;

high pressure

Ключевые слова:

лекарственнотехническое сырье; антиоксиданты; 
биологически

активные

вещества;

высокое давление;

барообработка альна данная проблема для населения, проживающего в районах с неблагоприятной экологической обстановкой. Цель исследования - изучить влияние обработки ЛТС высоким давлением на выход БАВ при его экстракции. Объектом исследования являлось высушенное ЛтС: крапива двудомная, мята перечная, душица обыкновенная, шалфей лекарственный, тысячелистник обыкновенный, зверобой продырявленный, чабрец, лист брусники, лист черной смородины и лист вишни урожая 2015-2016 гг., собранное в экологически благоприятных Нижнесергинском и Шалинском районах Свердловской области. Высушенное лТС обрабатывали высоким давлением при температуре $200{ }^{\circ} \mathrm{C}$ в системе Multivac следующим образом: пробу ЛтС массой 50 г помещали в загрузочный контейнер, затем направляли в камеру высокого давления. За счет камерных насосов генерировали давление 100; 150 и 200 мПа в течение 60 и 90 с. Установлено, что при обработке ЛТС высоким давлением наблюдалось увеличение количества аскорбиновой кислоты в экстрактах листа брусники на $63 \%$ в в крапиве двудомной - на 72\%; общее содержание флавоноидов в высушенном листе вишни выше на $37 \%$, а в душице обыкновенной - на $3 \%$ в сравнении с контрольными образцами. Выявлено, что оптимальными параметрами обработки ЛТС методом НРР являются 150 мПа в течение 90 с, при 200 мПа - 60 с. Указанные параметры НРР обусловливают разрушение молекул и межклеточной ткани, что положительно сказывается на извлечении БАВ в экстракте ЛТС. Показано, что в зависимости от повышения давления и увеличения времени воздействия АОА и содержание БАВ в исследуемом ЛТС после обработки возрастают.

\section{Introduction}

In the last years there is a tendency to use the natural ingredients for food production. The main statements of the government healthy eating policy are posed in the Federal Act № 29-FZ "About the food quality and security", National Food Quality Strategy in the Russian Federation until 2030, Demographic Policy Concept of the Russian Federation until 2025, Healthy Lifestyle Formation Concept of the Sverdlovsk Region till 2020. Its major principals are the health preservation and promotion, the life expectancy increase, conditions arrangement, the motivation for the healthy lifestyle, the significant incidence decrease in the social and dangerous to the public diseases, the chronic patient and invalid life quality improvement $t^{1,2}$.

According to The Basic Principles of State Policy of the Russian Federation in the field of population healthy nutrition for the period up to 2020 approved by the Government Resolution of the Russian Federation № 1873-R meeting the needs in a healthy diet of different population groups taking into account their traditions, habits and economic situation is necessary and up-to-date. Moreover, the Government Resolution of the Russian Federation № 559-R approved the Development Strategy for the Food and Processing Industries in the Russian Federation until 2020 providing with the new tech-

${ }^{1}$ The RF Government Resolution № 1346-r "On the Ratification of the Food Quality Increase Strategy in the Russian Federation until 2030". Dated 29.06.2016.

${ }^{2}$ Social and Economical Development Strategy of the Sverdlovsk Region until 2020. Ekaterinburg. 144 p. nologies development and implementation to expand the production range and volume of the new generation products with specified quality characteristics.

The long-term studies showed that a man was able to adjust the socially significant incidences rate by enriching the human diet with substances that had the opposite effect on the body and the function of healthy food ingredients. For example, cardiovascular diseases withstand the antioxidants such as vitamins $C$ and $E$, carotenoids, flavonoids, some inorganic elements and dietary fibers. According to Gorelikova G.A. and Pastushkova E.V., the use of vitamin $C$ and $\beta$-carotene helps to protect the body from gastric and lung cancer, respectively $[2 ; 4]^{3}$.

The development of new food of common and functional purpose impacted positively on the human body in the food industry is relevant. The amount of the biologically active substances in medical raw materials has a positive effect, especially on the population living in areas with a tense ecological situation.

In modern conditions the human diet cannot provide the body with the optimal amount of biologically active substances only by traditional food products, therefore, recently there has been a steady trend of population using food based on the vegetable raw materials in its diet.

${ }^{3}$ Method of the Solution Oxidative / Antioxidative Activity Test: Patent № 2235998. The Russian Federation. H.Z. Brainina, A.V. Ivanova: patentee: Ural State University of Economics, LLC "Scientific and Manufacturing Implementation Enterprise "IVA""; Published on 10.09.2004. 
Nowadays the innovative technologies development of the vegetable raw materials processing for the BAS extraction intensification purpose become of a great importance in the food industry. Modern methods of the biologically active substances extraction from the medical raw materials subdivided into traditional methods, such as extraction, and innovative methods with the use of modern technologies. Based on the basic provisions of the Fick law, there is an increase in the soluble BAS transition achieved due to the product grinding degree, temperature, pressure, process duration and hydrodynamic conditions [1]. These conditions allow to intensify the transition of biologically active substances in the extract.

One of the prospective methods is the food processing with high pressure, so called "High Pressure Processing". The method advantage is not only the chemical composition and nutritional value preservation of the vegetable raw materials, but also its consumer properties, including the required shelf life due to inactivation pathogenic microorganisms by the high pressure. A manufacturer concerns the economic component to be the HPP method advantage as the method allows to exclude the stage of preservatives introduction or bactericidal treatment in the medical raw materials from the technological process [3; 8-9; 11-12].

Nowadays there is an alternative method of barometric exposure. It is a comprehensive compression method using high pressure at ambient temperature $\left(20^{\circ} \mathrm{C}\right)$. The advantage of this method is not only the pathogenic microorganism inactivation, but also the intracellular vacuoles destruction, cell walls and cytoplasmic membranes of the plant material cells, that allows to increase the biologically active substances output in the medical raw materials extraction treated by this method.

The equipment using the comprehensive compression method is able to provide processing up to four tons of material per hour. Thus, the main HPP method advantages over other processing methods are isostatic effect; uniform pressure processing on the product; plant microbial cells inactivation.

Thus, the research purpose is to study the effect of high-pressure treatment on medical raw materials under comprehensive compression conditions on the BAS output during its extraction.

Objects and Research Methods

The research material was dryied medical raw materials: stinning nettle (Lat. Urtíca dióica), peppermint (Lat. Mentha piperita L.), wild majoram (Lat. Oríganum vulgáre), garden sage (Lat. Sālvia officinālis), sanguinary (Lat. Achilléa millefólium), amber (Lat. Hypéricum perforátum), thymus (Lat. Thymus serpyllum L), whortleberry leave (Lat. Vitis idaeae folia), black currant leave (Lat. Nigrum ribes folia) and cherry leave (Lat. Cerasus folia). The scientists gathered the harvest of the 2015-2016 in ecologically favorable Nizhneserginskiy and Shalinskiy areas. The main criterion for the raw materials selection was the antioxidants amount in them: P-active polyphenols, ascorbic acid, amino acids increasing the human body resistance [4].

A man run the chemical composition research of the medical raw materials after natural air-curing in the atmospheric air at the temperature of $25-30^{\circ} \mathrm{C}$ (Fig. 1). The air-curing was over when the following features were determined: leaf petioles and grass stems, leaves without excessive brittleness (to moisture content not more than $14 \%$ ). Flowers are to be dry to the touch. Dried fruits and seeds should not ball when gripping a fistful in a hand. Scientists adjusted the dried raw material to the appropriate standard condition: they removed parts that had lost natural colour, crushed pieces, tramp extraneous bodies [4-5]'.

${ }^{1}$ Method of the Solution Oxidative / Antioxidative Activity Test: Patent № 2235998. The Russian Federation. H.Z. Brainina, A.V. Ivanova: patentee: Ural State University of Economics, LLC "Scientific and Manufacturing Implementation Enterprise "IVA""; Published on 10.09.2004.

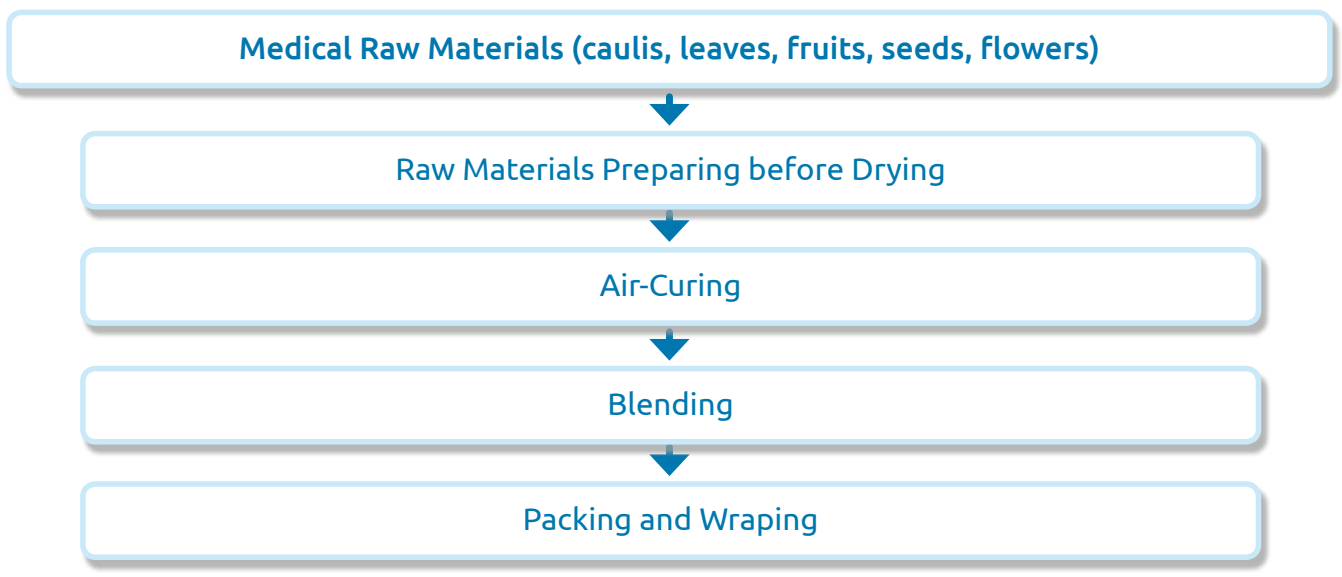

Figure 1. Technological Scheme of the Medical Raw Materials Air-Curing 
Table 1

Chemical Composition of Air-Cured Medical Raw Materials (2016 harvest), mg/100 g

\begin{tabular}{|l|c|c|c|c|c|c|c|}
\hline $\begin{array}{l}\text { Medical Raw } \\
\text { Materials }\end{array}$ & Vitamin E & Vitamin B1 & Vitamin B2 & Polyphenol & Vitamin B6 & $\beta$-carotene & Vitamin C \\
\hline $\begin{array}{l}\text { Stinging } \\
\text { Nettle }\end{array}$ & $0,2 \pm 0,06$ & $0,2 \pm 0,01$ & $0,2 \pm 0,01$ & $0,2 \pm 0,01$ & $0,2 \pm 0,01$ & $50 \pm 1,8$ & $185 \pm 4,6$ \\
\hline Peppermint & $0,15 \pm 0,058$ & $0,03 \pm 0,063$ & $0,1 \pm 0,01$ & $0,21 \pm 0,01$ & $0,03 \pm 0,003$ & $40 \pm 0,8$ & $14 \pm 2,4$ \\
\hline Wild Majoram & $0,05 \pm 0,003$ & $0,03 \pm 0,006$ & $0,03 \pm 0,005$ & $0,041 \pm 0,002$ & $0,03 \pm 0,033$ & $28 \pm 1,63$ & $192 \pm 4,2$ \\
\hline Garden Sage & $0,4 \pm 0,063$ & $0,01 \pm 0,005$ & $0,18 \pm 0,058$ & $0,012 \pm 0,0001$ & $0,02 \pm 0,006$ & $3,2 \pm 0,069$ & $20 \pm 1,9$ \\
\hline Sanguinary & $0,32 \pm 0,063$ & $0,37 \pm 0,041$ & $0,13 \pm 0,022$ & $0,034 \pm 0,0001$ & $0,04 \pm 0,015$ & $1,6 \pm 0,008$ & $30 \pm 0,9$ \\
\hline Amber & $0,28 \pm 0,018$ & $0,23 \pm 0,023$ & $0,14 \pm 0,053$ & $0,016 \pm 0,002$ & $0,1 \pm 0,023$ & $1,1 \pm 0,06$ & $70 \pm 0,05$ \\
\hline Thymus & $0,5 \pm 0,06$ & $0,19 \pm 0,014$ & $0,29 \pm 0,036$ & $0,029 \pm 0,001$ & $0,06 \pm 0,001$ & $0,5 \pm 0,058$ & $17 \pm 0,046$ \\
\hline Whortleberry & $0,01 \pm 0,001$ & $0,44 \pm 0,053$ & $0,19 \pm 0,06$ & $0,011 \pm 0,001$ & $0,19 \pm 0,004$ & $0,1 \pm 0,06$ & $13 \pm 0,6$ \\
\hline Black Currant & $0,03 \pm 0,0001$ & $0,15 \pm 0,001$ & $0,1 \pm 0,001$ & $0,01 \pm 0,001$ & $0,13 \pm 0,001$ & $0,1 \pm 0,001$ & $32 \pm 2,1$ \\
\hline Cherry & $0,02 \pm 0,0001$ & $0,10 \pm 0,06$ & $0,1 \pm 0,002$ & $0,01 \pm 0,0001$ & $0,03 \pm 0,001$ & $0,1 \pm 0,001$ & $21 \pm 1,8$ \\
\hline
\end{tabular}

The chemical composition analysis of the medical raw materials showed that all selected samples contained biologically active substances, and therefore might be the antioxidants source. When selected the medical raw materials from the table 1 once, its organoleptic characteristics including high aroma and complex flavor played an important role.

Researchers treated the dried medical raw material with high pressure at a temperature of $200^{\circ} \mathrm{C}$ in the Multivac system as following: they packed the MRM sample weighing $50 \mathrm{~g}$ in a vacuum transparent package at the preparatory stage and placed in a loading container. Then they sent the container to the high-pressure chamber, which was hermetically closed and filled with oil. Scientists generated pressure of $100 \mathrm{MPa}, 150 \mathrm{MPa}$, and $200 \mathrm{MPa}$ for 60 and 90 seconds by the chamber pumps. After fixed time they depressurized and emptied the chamber removing then the loading containers [3].

A man used the following general and special research methods in the work:

- determining the antioxidant activity by assessing the redox potential change before and after the introduction of the analyzed substance into a special solution containing a mediator pair ${ }^{1}$;

- determining the ascorbic acid content in accordance with the National State Standard 24556-89;

- using titrimetric methods with potentiometric or photometric titration with regard to the extract coloration;

\footnotetext{
1,3 Method of the Solution Oxidative / Antioxidative Activity Test: Patent № 2235998. The Russian Federation. H.Z. Brainina, A.V. Ivanova: patentee: Ural State University of Economics, LLC "Scientific and Manufacturing Implementation Enterprise "IVA" "; Published on 10.09.2004.
}

- determining the total bioflavonoids content in terms of rutin by the spectrophotometric method on the device after the complexation reaction with aluminum chloride at $\lambda=410 \mathrm{Nm}[5 ; 10]^{2}$.

Discussion of the Results

Researchers studied the antioxidant activity of the medical raw materials at the initial stage (fig. 2). The antioxidative activity is caused by the biologically active substances presence. The greatest role in the AOA are substances of the polyphenolic origin, vitamin $C$, organic acids, tannins and some amino acids. The presence of synergists substances is also of great importance. Synergists substances are electrons donors for antioxidants lost the electrons during the interaction with free radicals $[4 ; 10]^{3}$.

Scientists determined the AOA in the medical raw materials processed by the high pressure in a water extract (water duty 1:20). They revealed that the antioxidant activity of the analyzed medical raw materials processed by the high pressure increased depending on the pressure and processing time.

Stinging nettle $(0.18 \% \%)$ and currant leaf $(0.12 \%)$ have the antioxidant effect; wild majoram $(0.25 \%)$ and currant leaf $(0.19 \%)$ are full of polyphenols (bioflavanoids); amber (3.09\%) and sanguinary (1.43\%) - organic acids; amber (2.52\%) - amino acids and thyme $(0.6 \%)$ - the high content of vitamin $C$, respectively $[3-4 ; 6]$.

Scientists studied the ascorbic acid content, bioflavonoids and antioxidant activity of medical raw materials: the control sample (without high pres-

\footnotetext{
${ }^{2}$ The RF Government Resolution № 1346-r "On the Ratification of the Food Quality Increase Strategy in the Russian Federation" dated 29.06.2016.
} 


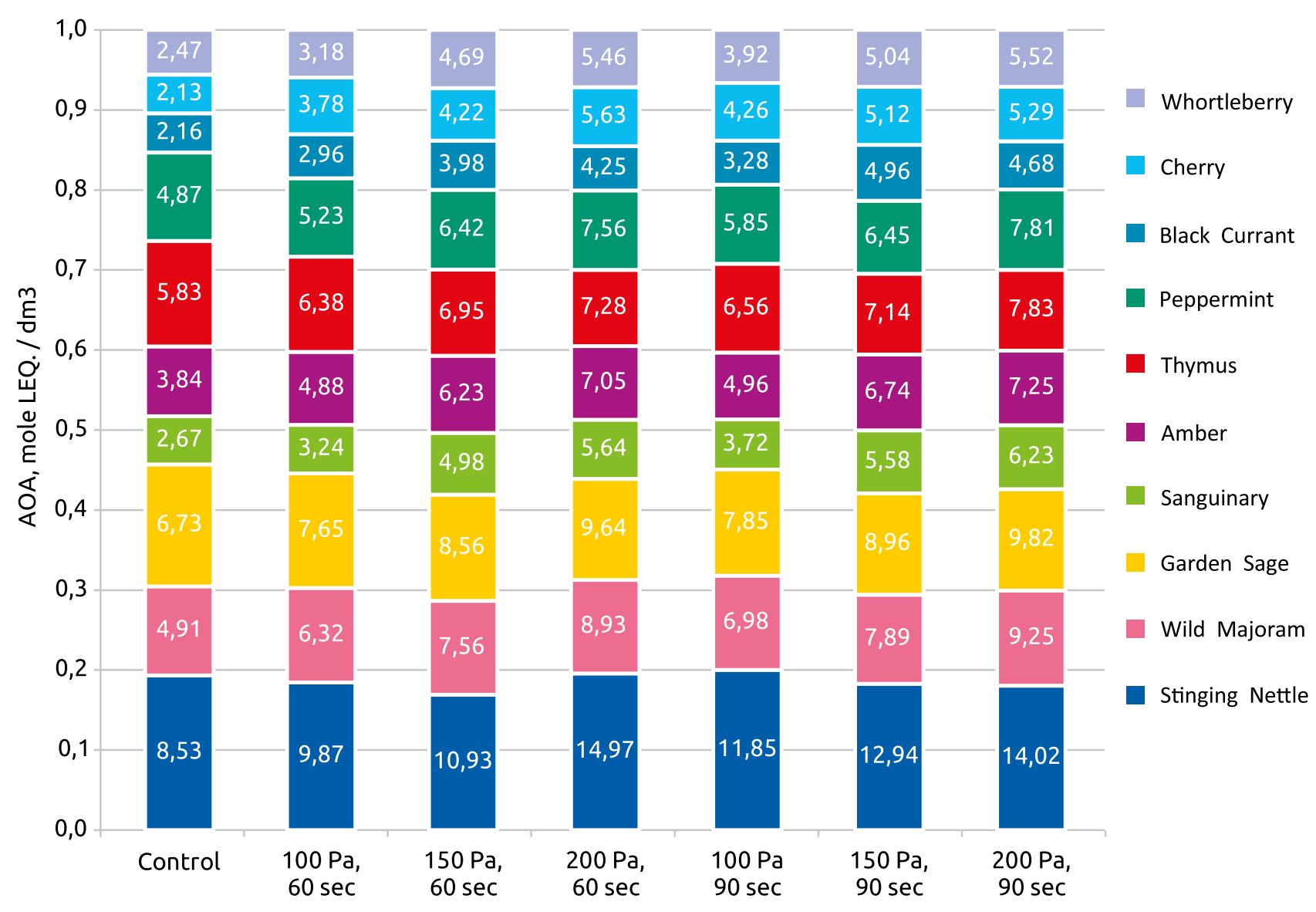

Figure 2. Antioxidant Activity of the Medical Raw Material Processing by the High Pressure

Table 2 The Content of Biologically Active Components in the Medical Raw Materials Treated by the High Pressure for 60 sec ( $n=3$ )

\begin{tabular}{|c|c|c|c|c|c|c|c|c|}
\hline \multirow{2}{*}{$\begin{array}{l}\text { Medical } \\
\text { Raw } \\
\text { Materials }\end{array}$} & \multicolumn{4}{|c|}{ Ascorbic Acid, mg/100g } & \multicolumn{4}{|c|}{ Bioflavanoids, Total*, mg/100g } \\
\hline & $\begin{array}{l}\text { Control } \\
\text { Sample }\end{array}$ & $100 \mathrm{~Pa}$ & $150 \mathrm{~Pa}$ & $200 \mathrm{~Pa}$ & $\begin{array}{l}\text { Control } \\
\text { Sample }\end{array}$ & $100 \mathrm{~Pa}$ & $150 \mathrm{~Pa}$ & $200 \mathrm{~Pa}$ \\
\hline $\begin{array}{l}\text { Stinging } \\
\text { Nettle }\end{array}$ & $185,3 \pm 4,6$ & $195,3 \pm 0,3$ & $215,8 \pm 0,4$ & $254,7 \pm 0,8$ & $1,821 \pm 0,02$ & $1,911 \pm 0,03$ & $1,956 \pm 0,06$ & $2,015 \pm 0,08$ \\
\hline Peppermint & $14,0 \pm 0,02$ & $14,6 \pm 0,03$ & $14,8 \pm 0,04$ & $14,3 \pm 0,06$ & $1,924 \pm 0,06$ & $1,948 \pm 0,03$ & $1,984 \pm 0,07$ & $1,994 \pm 0,02$ \\
\hline Wild Majoram & $192,2 \pm 0,42$ & $194,2 \pm 0,5$ & $195,7 \pm 0,7$ & $195,4 \pm 0,9$ & $2,514 \pm 0,03$ & $2,548 \pm 0,04$ & $2,565 \pm 0,5$ & $2,763 \pm 0,07$ \\
\hline Garden Sage & $20,0 \pm 1,8$ & $20,58 \pm 0,03$ & $21,48 \pm 0,06$ & $21,15 \pm 0,08$ & $1,612 \pm 0,01$ & $1,624 \pm 0,013$ & $1,652 \pm 0,016$ & $1,643 \pm 0,017$ \\
\hline Sanguinary & $30,0 \pm 0,3$ & $32,5 \pm 0,4$ & $35,63 \pm 0,8$ & $36,17 \pm 1,2$ & $1,659 \pm 0,01$ & $1,698 \pm 0,04$ & $1,701 \pm 0,05$ & $1,702 \pm 0,05$ \\
\hline Amber & $70,0 \pm 0,05$ & $73,8 \pm 0,06$ & $78,1 \pm 0,08$ & $79,13 \pm 0,18$ & $1,09 \pm 0,02$ & $2,23 \pm 0,02$ & $3,13 \pm 0,03$ & $3,54 \pm 0,07$ \\
\hline Thymus & $17 \pm 0,046$ & $17,7 \pm 0,5$ & $17,9 \pm 0,7$ & $18,4 \pm 0,9$ & $2,019 \pm 0,04$ & $2,139 \pm 0,08$ & $2,235 \pm 0,08$ & $2,365 \pm 0,09$ \\
\hline Whortleberry & $13 \pm 0,6$ & $14,6 \pm 0,03$ & $14,29 \pm 0,05$ & $15,31 \pm 0,07$ & $0,011 \pm 0,02$ & $0,025 \pm 0,02$ & $0,035 \pm 0,01$ & $0,034 \pm 0,015$ \\
\hline Black Currant & $32,0 \pm 0,01$ & $33,7 \pm 0,02$ & $34,2 \pm 0,02$ & $35,21 \pm 0,04$ & $0,512 \pm 0,03$ & $0,593 \pm 0,048$ & $0,687 \pm 0,052$ & $1,203 \pm 0,063$ \\
\hline Cherry & $21,0 \pm 0,05$ & $21,9 \pm 0,05$ & $23,61 \pm 0,07$ & $24,16 \pm 0,08$ & $0,01 \pm 0,003$ & $0,018 \pm 0,004$ & $0,204 \pm 0,007$ & $0,307 \pm 0,009$ \\
\hline
\end{tabular}




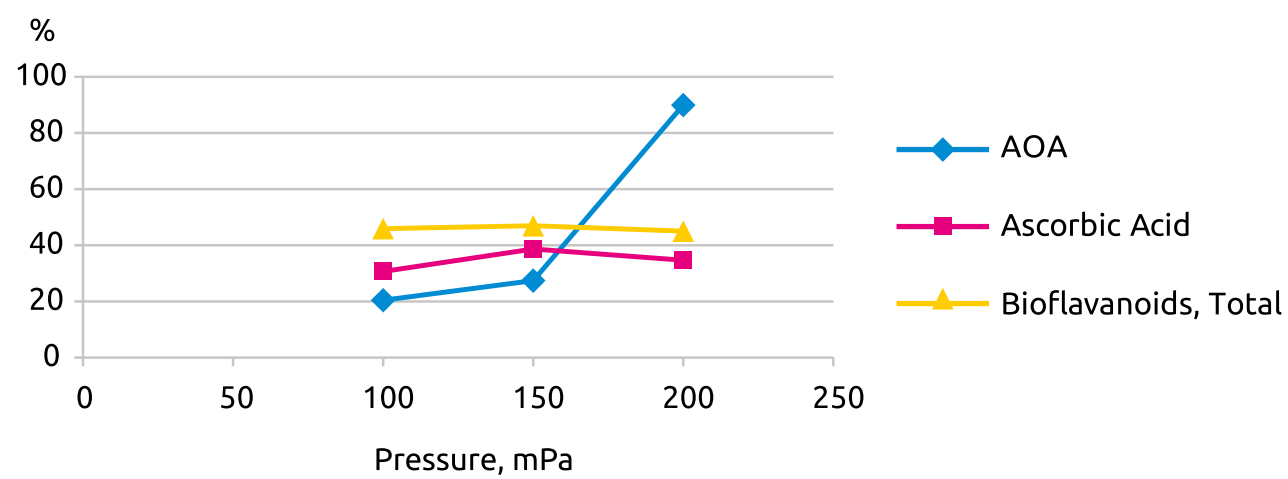

Figure 3. The Dependence of the Biologically Active Substances and Antioxidant Activity Content in the Medical Raw Materials Processed by the High Pressure for $60 \mathrm{sec}$

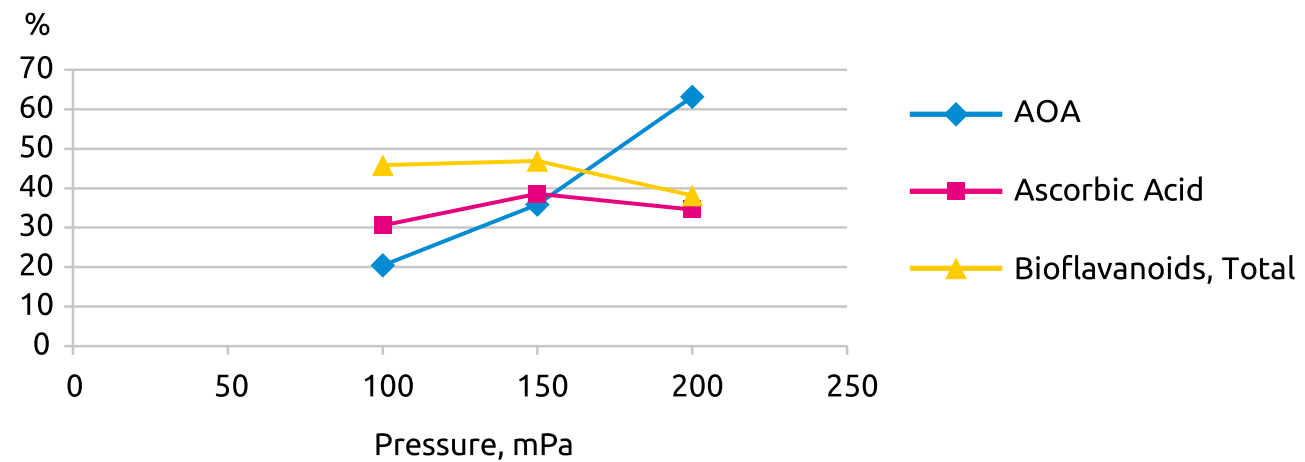

Figure 4. The Dependence of the Biologically Active Substances and Antioxidant Activity Content in the Medical Raw Materials Processed by the High Pressure for $90 \mathrm{sec}$

sure processing) and samples of medical raw materials with the different technological processing modes from the table 2 .

The data analysis presented in the table 2 shows that the high-pressure processing affects the intercellular membranes destruction and, as a result, has a positive effect on the BAS yield in the extract leading to a statement of its quantitative increase in the treated medical raw materials. So there was an increase in the ascorbic acid amount in the dried whortleberry leaf by $63 \%$, and in the stinging nettle by $72 \%$; the total flavonoids content in the dried cherry leaf raised by $37 \%$, and in the wild majoram - by $3 \%$, respectively, compared to the control samples.

Based on the results of the BAS and antioxidative activity study authors selected the optimal technological parameters of the medical raw materials processing by the high-pressure method in terms of the compression.
Results based on the biologically active substances and antioxidant activity content in the medical raw materials processed by the high-pressure method in terms of compression during 60 and 90 seconds shown on the figures 3 and 4 allow to conclude that the optimal exposure time for the pressure treatment of $200 \mathrm{mPa}$ is $60 \mathrm{sec}$, and of $150 \mathrm{MPa}-$ $90 \mathrm{sec}$, respectively. While the pressure processing of $100 \mathrm{mPa}$ the quantitative increase in the biologically active substances content in the extract was not significant (not more than 10\%).

Thus, the researchers discovered that the optimum medical raw materials treatment parameters by the high-pressure method are $150 \mathrm{mPa}$ within 90 seconds and $200 \mathrm{mPa}$ within 60 seconds. These parameters of the high-pressure processing lead to the molecules and intercellular substance destruction that has a positive effect on the biologically active substances extraction in the medical raw materials extract. 


\section{Bibliography}

1. Aver'janova E.V., Hmelev V.N., Cyganok S.N., Shakura V.A. Issledovanie processa izvlechenija BAV iz rastitel'nogo syr'ja v uslovijah ul'trazvukovoj jekstrakcii // XVIII Mezhdunar. konf.-seminara molodyh specialistov po mikro-i nanotehnologijam i jelektronnym ustrojstvam EDM: sb. st. Novosibirsk, 2017. $416 \mathrm{~s}$.

2. Gorelikova G.A. Nauchnoe obosnovanie i prakticheskie aspekty razrabotki i ocenki potrebitel'skih svojstv funkcional'nyh bezalkogol'nyh napitkov: avtoref. dis. ... d-ra tehn. nauk. Kemerovo, 2008. $32 \mathrm{~s}$.

3. Malishevskij A.A., Tihonov S.L., Tihonova N.V. Vlijanie predvaritel'noj obrabotki vysokim davleniem rastitel'nogo syr'ja na process jekstrakcii // Pishha. Jekologija. Kachestvo: tr. XIII Mezhdunar. nauch.-prakt. konf. / otv. za vyp.: 0.K. Motovilov, N.I. Pyzhikova, K.N. Nicievskaja. Krasnojarsk, 2016. S. 243-247.

4. Pastushkova E.V. Formirovanie potrebitel'skih svojstv chaja s dobavkami rastitel'nogo syr'ja antioksidantnoj napravlennosti: avtoref. dis. ... kand. tehn. nauk. Kemerovo, 2011. $16 \mathrm{~s}$.

5. Popov V.G. Razrabotka tehnologii proizvodstva poroshkoobraznyh bystrorastvorimyh koncentratov na osnove dikorastushhego lekarstvennogo rastitel'nogo syr'ja // Izvestija vuzov. Pishhevaja tehnologija. 2014. № 2-3. S. 56-59.

6. Chugunova 0.V., Zavorohina N.V., Pastushkova E.V. Ispol'zovanie rastitel'nogo syr'ja ural'skogo regiona pri modelirovanii bioprotektornyh svojstv chaja // Pishhevaja promyshlennost'. 2010. № 11. S. 42-44.

7. Ahn J., Balasubramaniam V.M. Effects of inoculum level and pressure pulse on the inactivation of Clostridium sporogenes spores by pressure-assisted thermal processing // J. Microbiol. Biotechnol. 2007. № 17. P. 616-623.

8. Furukawa S., Nakahara A., Hayakawa I. Effect of reciprocal pressurization on germination and killing of bacterial spores Int. // J. Food Sci. Technol. 2000. № 35. P. 529-532.

9. Hayakawa I., Kanno T., Yoshiyama K., Fujio Y. Oscillatory compared with continuous high, pressure sterilization on Bacillus stearothermophilus spores // Food Sci. 1994. № 59. P. 164-167.

10. Kriegenburg F., Ellgard L., Hartmann-Petersen R. Molecular chaperones in targeting misfoldedproteins for ubiquitin-dependent degradation // FEBS J. 2012. Vol. 279 (4). P. 532-42.

11. Pilavtepe-Çelik M., Buzrul S., Alpas H., Largeteau A., et all. Multipulsed high hydrostatic pressure treatment for inactivation and injury of Escherichia Coli. // J. Verbrauch. Lebensm. 2011. № 6. R. 343-348.

12. Rivalain N., Roquain J., Boiron J.M., et all. High hydrostatic pressure treatment for the inactivation of Staphylococcus aureus in human blood plasma // New Biotechnol. 2012. № 29. R. 409-414.

\section{Библиографический список}

1. Аверьянова Е.В., Хмелев В.Н., Цыганок С.Н., Шакура В.А. Исследование процесса извлечения БАВ из растительного сырья в условиях ультразвуковой экстракции // XVIII Междунар. конф.семинара молодых специалистов по микро-и нанотехнологиям и электронным устройствам EDM: сб. ст. Новосибирск, 2017. $416 \mathrm{c}$.

2. Гореликова Г.А. Научное обоснование и практические аспекты разработки и оценки потребительских свойств функциональных безалкогольных напитков: автореф. дис. ... д-ра техн. наук. Кемерово, 2008. 32 с.

3. Малишевский А.А., Тихонов С.Л., Тихонова Н.В. Влияние предварительной обработки высоким давлением растительного сырья на процесс экстракции // Пища. Экология. Качество: тр. ХІІІ Междунар. науч.-практ. конф./ отв. за вып.: О.К. Мотовилов, Н.И. Пыжикова, К.Н. Нициевская. Красноярск, 2016. C. 243-247.

4. Пастушкова Е.В. Формирование потребительских свойств чая с добавками растительного сырья антиоксидантной направленности: автореф. дис. ... канд. техн. наук. Кемерово, 2011. 16 C.

5. Попов В.Г. Разработка технологии производства порошкообразных быстрорастворимых концентратов на основе дикорастущего лекарственного растительного сырья // Известия вузов. Пищевая технология. 2014. № 2-3. С. 56-59.

6. Чугунова О.В., Заворохина Н.В., Пастушкова Е.В. Использование растительного сырья уральского региона при моделировании биопротекторных свойств чая // Пищевая промышленность. 2010. № 11. С. 42-44.

7. Ahn J., Balasubramaniam V.M. Effects of inoculum level and pressure pulse on the inactivation of Clostridium sporogenes spores by pressure-assisted thermal processing // J. Microbiol. Biotechnol. 2007. № 17. P. 616-623.

8. Furukawa S., Nakahara A., Hayakawa I. Effect of reciprocal pressurization on germination and killing of bacterial spores Int. // J. Food Sci. Technol. 2000. № 35. P. 529-532.

9. Hayakawa I., Kanno T., Yoshiyama K., Fujio Y. Oscillatory compared with continuous high, pressure sterilization on Bacillus stearothermophilus spores // Food Sci. 1994. № 59. P. 164-167.

10. Kriegenburg F., Ellgaard L., Hartmann-Petersen R. Molecular chaperones in targeting misfoldedproteins for ubiquitin-dependent degradation // FEBS J. 2012. Vol. 279 (4). P. 532-42.

11. Pilavtepe-Çelik M., Buzrul S., Alpas H., Largeteau A., et all. Multipulsed high hydrostatic pressure treatment for inactivation and injury of Escherichia Coli. // J. Verbrauch. Lebensm. 2011. № 6. P. 343-348.

12. Rivalain N., Roquain J., Boiron J.M., et all. High hydrostatic pressure treatment for the inactivation of Staphylococcus aureus in human blood plasma // New Biotechnol. 2012. № 29. P. 409-414. 
Pastushkova Ekaterina Vladimirovna

Пастушкова

Екатерина

Владимировна

Тел./Phone: (343) 221-27-59

E-mail:pas-ekaterina1@yandex.ru

Khabarov

Stanislav Nikolaevich

Хабаров

Станислав Николаевич

Тел./Phone: (385) 268-50-65

E-mail: niilisavenko@hotbox.ru
Candidate of Technical Science, Associate Professor, Associate Professor

of the Merchandise and Expertise Department

Ural State University of Economics

620144, Russia, Ekaterinburg, 8 March St. / Narodnoy Voli St., 62/45

Кандидат технических наук, доцент, доцент кафедры товароведения и экспертизы Уральский государственный экономический университет 620144, РФ, г. Екатеринбург, ул. 8 Марта/Народной Воли, 62/45

Member of the Russian Academy of Sciences, Laureate of the USSR Government Reward in Science and Technology, Honored Scientist of the Russian Federation, Doctor of Agricultural Science, Professor, Director of the Industrial Technology Centre Institute of Siberia Horticulture n.a. M.A. Lisavenko 656045, Russia, Altai Territory, Barnaul, Zmeinogorskiy highway, 49

Академик РАН, лауреат Государственной премии СССР в области науки и техники, заслуженный деятель науки РФ, доктор сельскохозяйственных наук, профессор, руководитель Центра индустриальных технологий нИИ садоводства Сибири им. М.А. Лисавенко 656045, РФ, Алтайский край, г. Барнаул, Змеиногорский тракт, 49 